\title{
REVIEW
}

\section{Regulatory issues for genetically modified animals}

\author{
Perry Bradbury HACKETT (凶) \\ Center for Genome Engineering, Department of Genetics, Cell Biology and Development, University of Minnesota, Minneapolis, \\ MN 55455, USA
}

\begin{abstract}
Precision genetics and breeding have the potential to meet the agricultural needs and goals of the world in the 21 st century. These needs include increasing the efficiency of production of animals and improving their products with minimal impact on the environment. The USA is the major innovator in genomic science and the acknowledged leader in formulating policies to regulate genetic applications in medicine and agriculture. However, governments worldwide have been exceedingly reluctant to support the introduction of genetically modified (GM) animals into agriculture. Regulatory policies have stagnated due to legal guidelines that could not anticipate the needs and solutions that are evident today. This must change if we are to maintain planetary integrity. I propose a new, market-based regulatory model for GM livestock that has both a strong scientific foundation and has worked for 10000 years. The model is similar to that for information technology in which specific algorithms drive computer and cell phone applications. Genome engineers write genetic algorithms that drive the traits in biological organisms. Accordingly, GM products should be viewed in terms of their use and public benefit rather than by limitations to the genetic programing coming from a few highly vocal groups. Genetic algorithms (Genapps) of the 21 st century will include not only introduction of synthetic genes, but also complete natural and synthetic biochemical pathways to produce agricultural products that are maximally efficient, healthy to humans and animals, and sustainable in an era of changing climates while avoiding environmental degradation.
\end{abstract}

Keywords algorithms, editing, FDA, GMO, recombinant DNA, USDA

Received November 15, 2019; accepted December 24, 2019

Correspondence: hacke004@umn.edu

\section{Introduction}

All enduring entities such as buildings, countries and belief systems are based on solid foundations. Agriculture has been the most enduring entity in the history of the world because over the past 10000 years humans have devised methods of increasing efficiency in the quality and quantity of crops and animals by selective breeding of available stocks. In the mid-twentieth century agriculture was failing. Global hunger was addressed by Borlaug ${ }^{[1]}$ who spearheaded the first Green Revolution through systematic hybridization of the major crops (Fig. 1(a)). The Green Revolution was based on blindly mixing thousands of alleles of unknown genes with each other, planting the seeds without any regulation, taking what emerged, and looking for increases in crop yields in diverse environments without any thought to genetic details. This worked until the Green Revolution began falling behind what is necessary to adequately feed the world (Fig. 1(b) $)^{[2,3]}$. Borlaug predicted that biotechnology and genetic engineering would be the basis for a second Green Revolution $^{[1,4]}$ that would be needed to double the world's food supply by 2050 from that in $2009^{[5,6]}$. Likewise, the U.S. National Academy of Sciences Committee called for a 10-fold genetic improvement in livestock, poultry, and aquaculture populations by $2030^{[7]}$. Higher productivity is vital for sustainable global crop and animal agriculture $^{[8-10]}$.

Today, agriculture is challenged not only by increasing numbers of people (Fig. 2(a)) demanding increasing standards of living that include better diets and more energy consumption per individual (Fig. 2(b)), but also global climate change due to increases in atmospheric $\mathrm{CO}_{2}$ resulting from greater energy consumption and increased agricultural activity (Fig. 2(a)). Genome engineering of crops and animals can contribute to solving anticipated world hunger and environmental degradation ${ }^{[11,13-18]}$. However, this is unlikely due to current regulations of genetically modified (GM) agricultural products that were enacted decades ago. Over this time two activities 
(a)

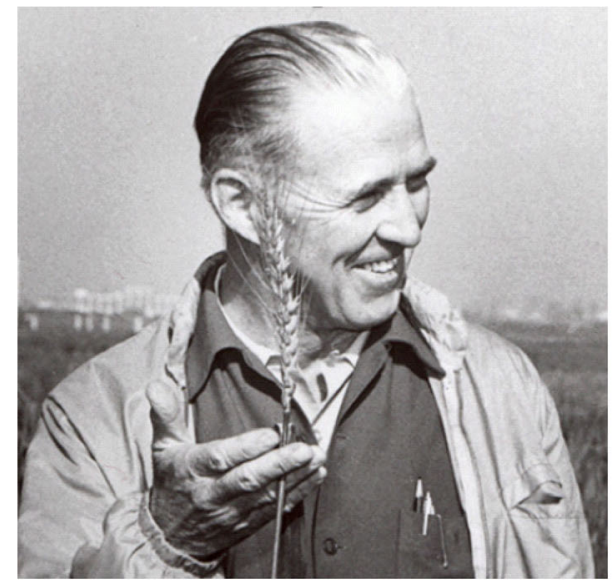

(b)

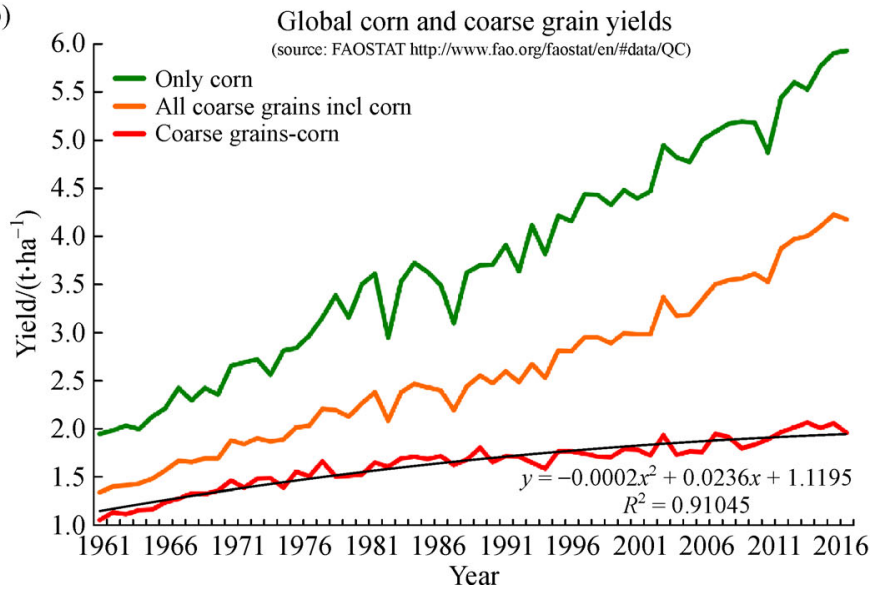

Fig. 1 (a) Norman Borlaug (source: University of Minnesota with permission). (b) Yields of major coarse grains showing all grains except corn/maize (red line) with a best fit quadratic and total yields of corn/maize (green line) that is used predominantly for production of ethanol, feed for livestock, and high fructose corn syrup. The orange line shows the averaging of yields when corn is added to the other grains. (Graph is provided by Dr. Deepak Ray ${ }^{[2]}$ with permission).

(a)

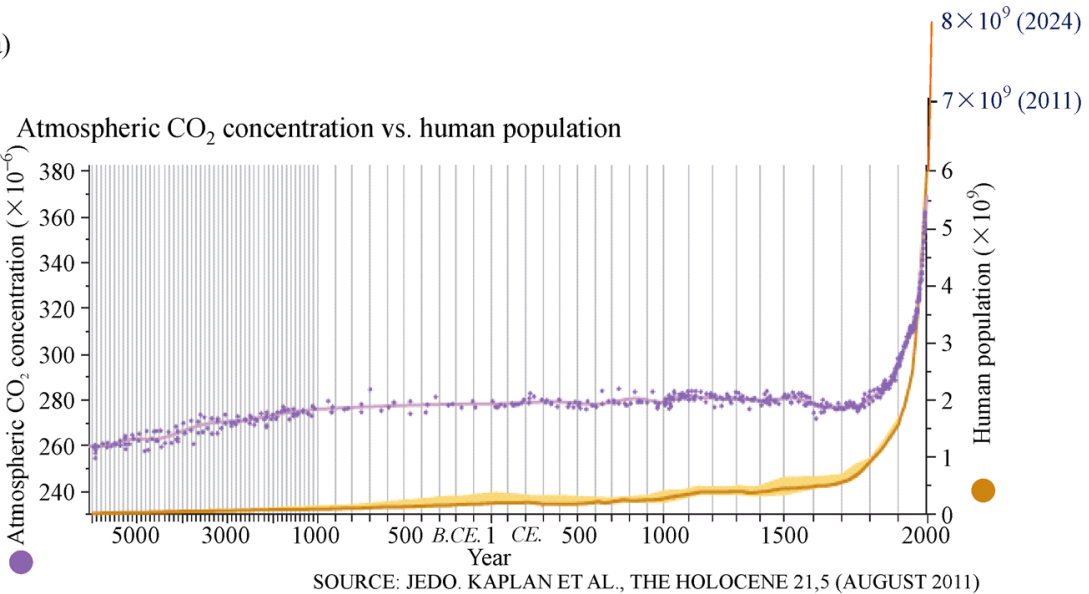

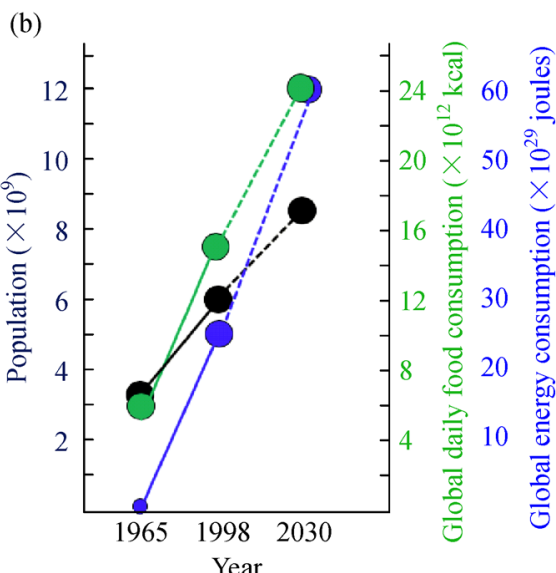

Fig. 2 The world is changing. (a) World population and atmospheric $\mathrm{CO}_{2}$ levels, adapted from Kaplan et al. ${ }^{[11]}$. (b) Projections of global daily caloric intake per person and global energy usage, adapted from Graham-Rowe ${ }^{[12]}$.

flourished. First, unspoiled lands, e.g., the Amazon rainforest, have been turned over to agriculture ${ }^{[19,20]}$. Second and concurrently, the scientific community expanded its understanding of genetic mechanisms to the point of enabling reliable, precision changes in whole genomes $^{[21,22]}$ through a process called genome editing (GE). With an accuracy equivalent to changing a single character in 1000 books, GE is poised to increase the agricultural productivity of livestock and crops $^{[23-30]}$, especially in China ${ }^{[31-33]}$. Clearly, this is the time to reform the regulation of GM and GE agricultural products. Accordingly, there are discussions to revise regulations on GM agricultural products in the USA ${ }^{[34-39]}$ and several other countries $^{[40,41]}$.

\section{Proposed revision of regulatory policies for GM animals for the 21st century}

Two general ways to regulate GM animals are shown in Fig. 3. The first way is the traditional way for agriculture that has endured for more than 10000 years with extraordinary gains in productivity (Fig.3(a)). More importantly, this method has worked for 70 years worldwide for hybridized crops. A market-based regulatory pathway lets consumers determine the value of a given line of animal. Design and sales of animals are based on the criteria of breeders and distributors, who have a deep understanding of valuable versus inferior traits and genetic effects that would lower the value of an animal. In contrast, 
(a)

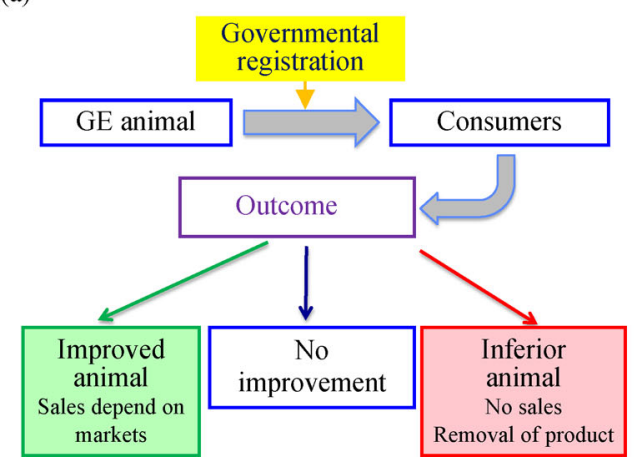

(b)

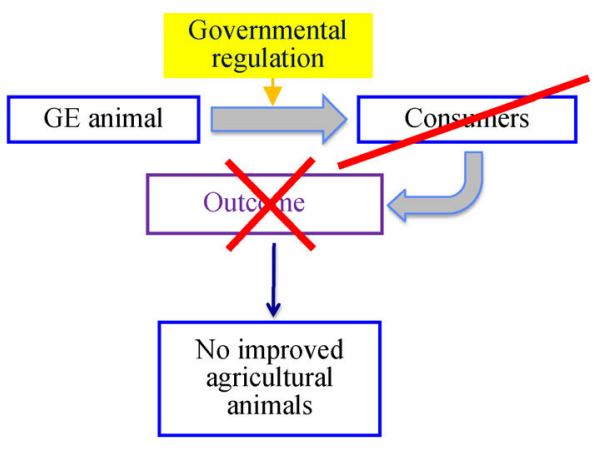

Fig. 3 Models for regulation of genetically modified (GM) animals. (a) Proposed regulatory pathway. Producers sell GM animals to breeders who then sell to farmers and ranchers with minimal governmental registration to assure the public that the products are transparent. The outcomes are evaluated by the public markets. Good products are amplified as sales increase; if a bad product enters the market, correction is swift. (b) Current regulatory pathway. GM animals must pass review by government regulators before release to consumers. The criteria for passage are ill-defined, slow to change and hence expensive, time-consuming and uncertain. The result has been few new products, no new improvements and citizen uncertainty about safety.

Fig. 3(b) shows the current state of affairs wherein governments have effectively stifled innovative applications of GM technology to animals by, in essence, invoking the precautionary principle. This blocks the release of a product if there could be unanticipated consequences. The Precautionary Principle that heeds the concerns of extremely vocal people with little scientific understanding ${ }^{[42]}$ has always dominated deliberations and decisions.

Of course, everyone's view must be acknowledged by regulators. Accordingly, in the market-based regulatory model (Fig. 3(a)), government registration is essential, mainly to certify that the products do not have any evident feature that would compromise the health of consumers beyond what is currently allowed. This concept is congruent with current policies of the U.S. Department of Agriculture's Food Safety and Inspection Service (USDA-FSIS) that does ante-mortem inspections of all animals to ensure that only healthy animals enter the food chain $^{[43]}$. Due to their need to be reproduced, lines of GM animals that are defective in an unanticipated way would be withdrawn at economic loss to the breeders and farmers in the same way that flawed hybrid variants from the Green Revolution never make it to the table.

The market-based approach is actually more risk-free compared to pre-release regulation. Agricultural markets are highly competitive. Those in the animal and plant genetics businesses know the value of every trait in their variants and they recognize deficiencies quickly. GM animals will not be released to the public until herds are developed, which requires rounds of reproduction during which each animal is scrutinized for overall value and fitness. The abilities of experienced users are respected by giving them the freedom to introduce major improvements and diversity in their products to meet 21 st century needs.

Given the huge success of the Green Revolution, we can realistically consider a scientifically sound, more efficient way to approach the regulation of GM animals that supports innovation. Genome engineers essentially write genetic algorithms using $\mathrm{A}, \mathrm{G}, \mathrm{C}$, and $\mathrm{T}$ just as computer programmers manipulate 0 and 1 (Fig. 4). People are used to "apps" evolving in number and quality to improve their lives (Fig. 4(b)). Bad apps are withdrawn ${ }^{[45]}$ because negative publicity kills any product. Just as with computer applications, genome programmers have the ability to produce useful Genapps that will appeal to different groups of consumers who have their own particular needs.

The problem is that everyone seems to have been conditioned over decades of questionable discourse that GM foods are tainted. Superficially it would seem better to be overcautious than endanger people with a new technology that affects the food they eat. However, current regulations of GM agricultural products that stress genomic purity are irrelevant to consumer safety. To understand why, we must look at what spawned government regulation of GM (transgenic) animals.

\section{How we got to the current regulatory policies for GM animals}

The story starts 60 years ago with the discovery of restriction endonucleases ${ }^{[46]}$ that were harnessed to construct recombinant DNAs. The history of genetic engineering with an emphasis on animals has been reviewed ${ }^{[47]}$. Briefly, as recombinant DNA technology developed, concerns were raised about misuse of powerful genetic technologies. The concerns stemmed from previous worries of scientists following the atomic bomb blasts that ended World War II. The potentially destructive consequences of atomic energy raised questions as to whether the technology should have been developed and deployed in the first place, a concern emphasized by the 
(a)

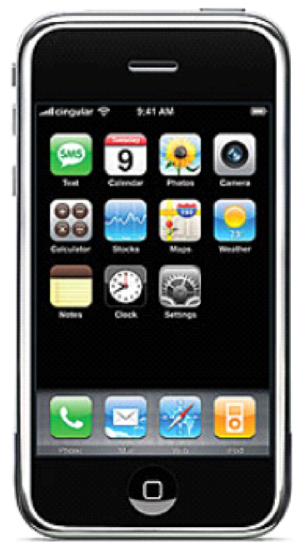

Jun. 2007

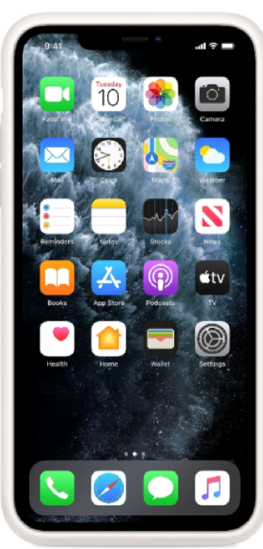

Jul. 2017 (b)

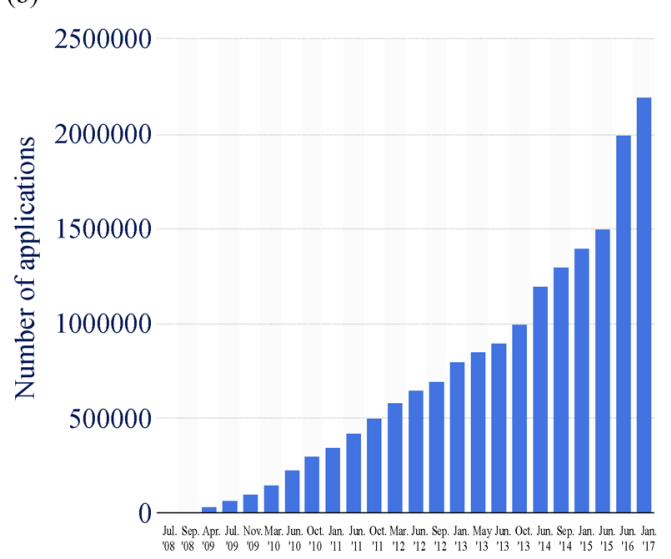

Jul. 2008 (c)

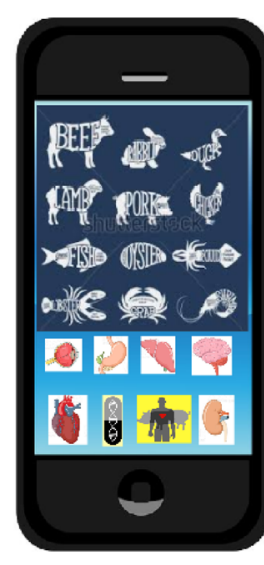

Future

Fig. 4 Algorithm-based applications drive progress. (a) Evolution of the iPhone over a decade. (b) Exponential growth in applications for the iPhone over 11 years (adapted from Statista ${ }^{[4]}$, (C) Statista 2020). (c) Imaginary icon showing biological apps based on genetic algorithms.

Bulletin of the Atomic Scientists that featured a doomsday clock on its cover. Another perturbing memory was that of Simian Virus 40 (SV40) that causes cancer in primates; it was revealed to be a contaminant in early polio vaccines in the $\mathrm{USA}^{[48]}$. As it turned out, the virus did not productively replicate in humans (phew!). The public was pretty much unaware of the concerns of scientists. However, Michael Crichton's book and film, The Andromeda Strain, did put the public on edge about recombinant DNA. All of these influences resulted in the Asilomar Conference on the northern California coast ${ }^{[49]}$ that issued a detailed set of recommendations to limit recombinant DNA research. This was a scientific endorsement of the better safe than sorry position.

Twenty years later it was clear that all of the terrifying scenarios were unrealistic ${ }^{[50]}$. We found that there are major differences in the way genetic information is regulated and processed in bacteria compared to plants and animals, analogous to the differences in information processing in Apple versus MS Windows computers. As a result, effective expression of bacterial genes in plant and animal cells is extremely unlikely outside a molecular biology laboratory and vice versa. The consequences of failure to understand these basic differences, as well as the astonishing plasticity of genomes, led to the stifling of applications of precision genetics to agriculture that exists today.

Regulation in the USA was impaired further by the division of oversight for different GM organisms (Fig. 5). Although the concerns seemed to be the same, from the beginning policies differed greatly between the agencies. The Office of Science and Technology Policy established a Coordinated Framework for Biotechnology Regulation ${ }^{[51]}$ to avoid writing new laws, which take considerable time and rarely emerge from Congress as initially planned.
Accordingly, the U.S. Department of Agriculture (USDA) regulates plants under the Plant Protection Act and is required to consider whether a genetic modification results in the creation of a new plant pest. Similarly, the U.S. Environmental Protection Agency (EPA) regulates pesticides and consequently GM insects. The U.S. Food and Drug Administration (FDA) got GM animals. It had to find a legal umbrella to do so. Under the New Animal Drug rubric, FDA considers GM animals, and more specifically any genetic modification they contain, as a drug. A New Animal Drug Approval is a file established by FDA after the "drug" is approved. The New Animal Drug must adhere to pharmaceutical standards as defined Guidance for Industry on Regulation of Genetically Engineered Animals Containing Heritable recombinant DNA Constructs; Availability (Docket No. FDA-2008-D-0394) in the January 16, 2009. In essence, a transgenic fish was to

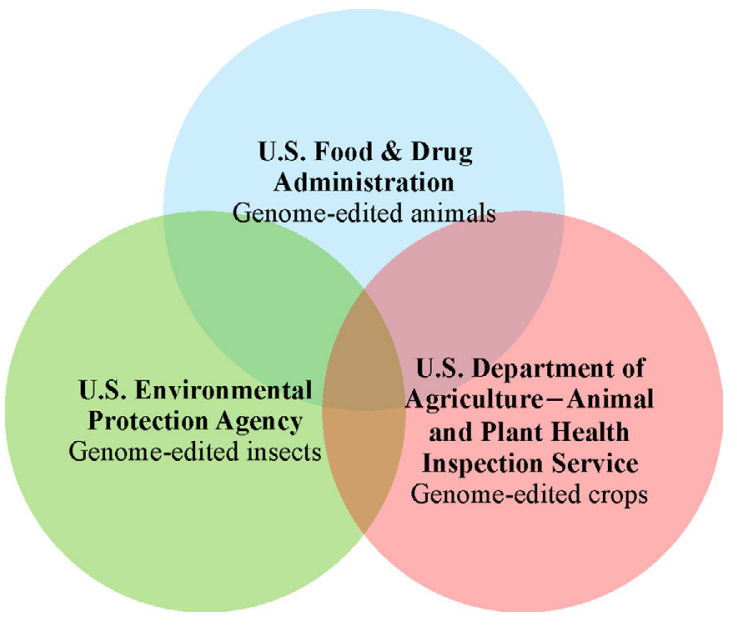

Fig. 5 Regulatory overlap of GM organisms by U.S. agencies. 
be treated like an aspirin, i.e., a precise chemical formulation.

Life may be based on chemical reactions, but animals are not simple, definable chemical formulations that are unchanging over generations. Consequently, figuring out how to fit living animals into a drug category has been problematic for both developers and regulators; it is a modern version of the harrowing Greek myth of Procrustes in which people were forcefully fitted into inappropriate beds. The result has been that only one GM food animal, Aquabounty's growth-enhanced salmon, has emerged from a politicized, regulatory morass ${ }^{[52,53]}$.

The differences between USDA and FDA regulations of GM products are staggering. Generally speaking, FDA is concerned with the safety of the consumer who eats a GM product that is potentially contaminated with suspect DNA sequences whereas USDA is concerned with potential environmental contamination by the crop holding the genetic modification. Genetic engineering of plants ${ }^{[54]}$ came years after that in mice ${ }^{[55-58]}$; the first transgenic fish came even later ${ }^{[59]}$. The rapid progress in genetic engineering of animals was the result of (1) strong financial support by the U.S. National Institutes of Health (NIH) to develop advanced medical therapies, including human gene therapy, and (2) the relative ease in introducing transgenic DNA into animal cells compared to the difficult procedures required in plants. However, despite the scientific challenges of genetic in engineering of plants, and the far greater propensity of transgenic pollen and seed to spread in the wind, planting of GM crops ${ }^{[60]}$ has monotonically increased over two decades to encompass about $14 \%$ of all arable land (Fig.6(a)). Transgenic crops are a huge part of the U.S. bioeconomy (Fig. 6(b)). The GM agricultural sector is comparable to GM-based biomedical applications (biologics). GM animals are missing from the figure because there are none except fluorescent pets, GloFish. GM animals have

(a)

Contribution of GM crops to global agriculture

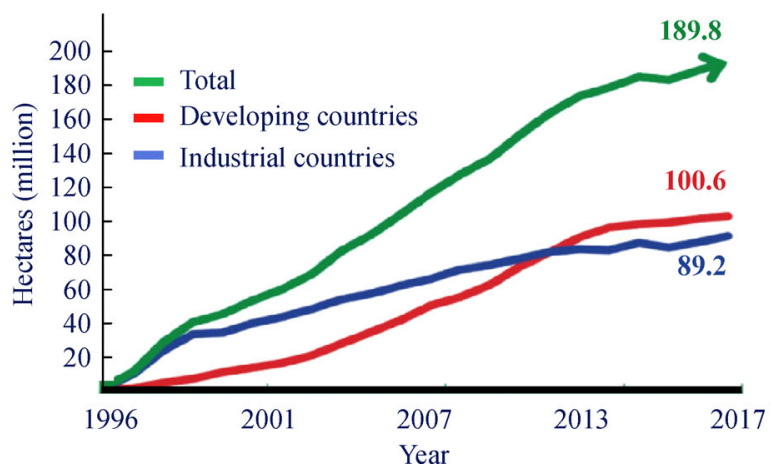

immense potential to contribute globally to food security, and global economies while helping to save the environment.

The consequences of delaying approval of GM animals is not just about the loss of improved agricultural animals, but is of greater concern for the future. The number of large-animal, genome-engineering students in U.S. universities is minimal. There are few fellowships and incentives in animal genomic engineering because there no jobs. It will take the USA years to catch up applying technologies its scientists invented and developed. It is not a matter of intellectual property theft; it is a matter of failure to capitalize on investments U.S. citizens have already made in precision genetics ${ }^{[63]}$.

The USDA has tried to adapt to advances in genome engineering ${ }^{[64,65]}$. USDA does not currently regulate or have any plans to regulate plants that could otherwise have been developed through non-GM breeding techniques. This position allows introducing deletions, single basepair mutations and insertions from compatible plant relatives into recipient plant genomes. This seems dramatically enlightened compared to FDA policies; but it could actually be considered minimal in terms of the collective understanding of what GM has to offer agriculture. For instance, regulatory guidance documents ${ }^{[64,65]}$ direct that only one change be made at a time based on abilities to detect genetic mutations that occur with a $10^{-6}$ chance in nature. To make two such changes, stacking of traits would occur at a rate of $10^{-6} \times 10^{-6}=10^{-12}$. Since these odds are considered highly unlikely in the real world, two or more changes at the same time are not given an automatic pass. It is allowable to perform the genetic steps in sequential generations, which appears to be based on a belief that natural is safer. It's not. For instance, irradiating germplasm in animals and plants is not regulated ${ }^{[66]}$ because it has historical precedent. In fact, early geneticists used X-rays to induce mutations in fruit flies (Drosophila

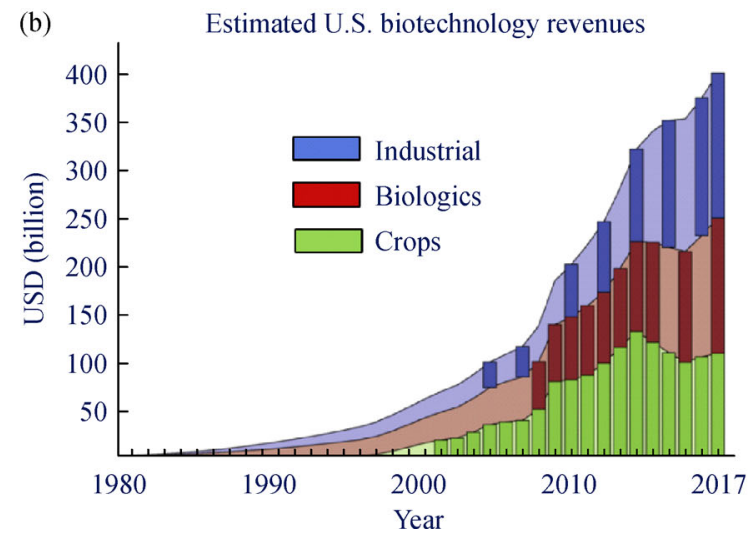

Fig. 6 Contribution of GM crops to world agriculture and the U.S. economy. (a) The steady adoption over the past 20 years of GM crops worldwide (source: International Service for the Acquisition of Agri-Biotech Applications (ISAAA) ${ }^{[61]}$ ). (b) U.S. biotechnology revenues (extrapolated) from 1980 to 2017 based on Carlson ${ }^{[62]}$. The bars are data, while shaded areas are a numerical model pinned at 0 USD revenues in 1980 (1996 for GM crops). 
melanogaster) that resulted in monsters; the double-thorax flies with a double set of wings and the antennapedia mutation that resulted in legs sprouting from the eyes (Fig. 7); precision genetics will not produce such animals. A further example of governments attempting to satisfy the public is the National Bioengineered Food Disclosure Standard enacted by Congress in order to introduce a comprehensive labeling policy rather than a plethora of different laws in various states. The financial consequences of the federal law will be hundreds of millions of dollars even though the agencies have no expectations that the disclosures on food will have any value to the consumer ${ }^{[68]}$. These examples demonstrate the difficulties governmental agencies have in accommodating divergent public opinions on GM organisms.

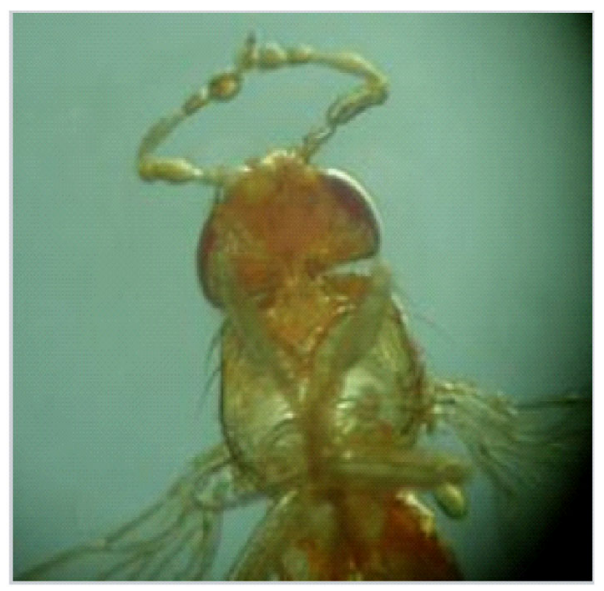

Fig. 7 Example of a classical Antennapedia ${ }^{[67]}$ developmental mutant found from X-ray mutagenesis of Drosophila melanogaster. (source: CC BY SA 3.0).

Nevertheless, there is hope. Recent Pew Center polls ${ }^{[69,70]}$ show that the fear of genetic engineering is decreasing with nearly half of Americans approving GM food animals. In contrast, only about a quarter of those polled approve of the use of GM technology in pet fish, GloFish, which is ironic given that an estimated 50 million to 100 million have been sold in the United States and Canada. There appears to be an inverse relationship between a person's level of scientific knowledge and their level of opposition to GM foods ${ }^{[42,70]}$.

In contrast to USDA, FDA regulations do not appear to respect the tremendous gains of genetic information scientists have achieved over the past three decades that have addressed essentially all of the concerns of the 1970s and 1980s. Specifically, the recent FDA revision of Guidance \#187 for Industry - Regulation of Intentionally Altered Genomic DNA in Animals, dated January 2017 $7^{[71]}$ states that all GM animals, even those with precision changes of defined sequences (i.e., GE) will be "deemed unsafe" due to their "adulterated" genomes. This position is a belief and not founded in scientific fact. It is also insulting to scientists who spend years thinking about what they believe will both solve current problems and best make the world a better place. This initial position that genome modifications in animals are likely to be deleterious and/or contaminating needs changing to accommodate GM animals that will benefit the people, the animals themselves, and the environment.

\section{Are there recognized food-safety issues with GM animals?}

The principal public concerns in the 1980s over all GM products, plants and animals, were (1) they were unnatural and potentially unsafe, (2) transgenes might escape and thereby reduce natural diversity, (3) the engineering might lead to suffering of the animals, and (4) scientists were playing God, while a few greedy mega-corporations had total control of GM products, and others.

What has emerged over recent decades is that transgenic foods are safe by every measure. That makes sense; the diversity of human consumption is vaster than what any individual consumes. Humans eat nearly everything that walks, slithers, flies, crawls or swims. Most people enjoy eating "foreign" foods because of their exotic tastes, which are often due to spices that are the most contaminated, feces-ridden, urine-soaked ingredients we ingest ${ }^{[72]}$. The fear of a foreign gene in food is an emotional issue and should be taken in the context of how many genes we eat. For instance, $100 \mathrm{~g}$ (about a quarter pound) of meat or fish contain approximately $10^{15}$ genes, about which very little is known. Rightfully, the concern should be about the GM animal in its entirety rather than the DNA sequence in its genome. This is what the genome engineers and breeders understand and the regulatory agencies should be certifying.

Regarding the other three issues, (1) the possibility of escape of transgenes into the environment is nearly impossible from agricultural animals due to their high level of containment. In crops unwanted introgression of transgenes into wild plants has been observed ${ }^{[73,74]}$ but the consequences have been small compared to the benefits (Fig. 6). (2) Concerns of pain and suffering of animals engineered with only productivity in mind have been addressed ${ }^{[75]}$. Recently, improved animal welfare in cattle was the principal goal in two genome engineering projects - one that obviated the pain associated with dehorning by introduction of the polled allele ${ }^{[76]}$ and the second that increased tolerance to heat and humidity by introgression of the slick allele ${ }^{[77]}$. (3) Ethical issues related to playing God are not addressable by scientists except to note that humans employ technologies in every aspect of their lives that allow us to transcend natural limitations. The other social issue, concerns of a very few international corporations controlling the $\mathrm{GM}$ and $\mathrm{GE}$ 
market, is valid. The costs of developing a new GM product are much lower than the costs in time and money of meeting regulatory standards required to bring a product to market. That is, excessive, misplaced fears of GMOs have led to excessive regulatory controls that only rich companies can surmount. Revising regulatory policies in accord with current scientific understanding of risks and benefits would help dispel fears of GM products being totally controlled by mega-corporations and allow many small companies to enter the bioeconomy.

\section{Regulatory concerns}

FDA has particular concerns with recombinant DNA expression cassettes that may be introduced randomly into GM animal genomes. The following were issues in the 1980s: (1) insertional mutagenesis that might affect the activity of a resident gene and imprecision of control of expression of transgenes and unstable expression of the transgene due to epigenetic effects, (2) effects of prokaryotic DNA sequences accompanying the transgene, and (3) concerns that transgenes could spread to other organisms. Although GE avoids issues that may derive random integration, it is important to be proactive and address concerns of any form transgenesis in GM animals because future introduction of whole pathways into animal genomes will be needed to achieve environmental goals such as significantly reducing greenhouse gases from agricultural products.

5.1 Concerns of insertional mutagenesis and instability of transgene expression

The concerns of insertional mutagenesis mis-regulation by endogenous genetic control elements was exacerbated by the results of gene therapy for boys with X-linked severe combined immunodeficiency disease ${ }^{[78]}$. Within a couple of years, the problem was generally solved ${ }^{[79,80]}$ with few further severe adverse insertional incidences for monogenic diseases ${ }^{[81,82]}$. The issue of instability of transgene expression is not an issue as this would be equivalent to reversion of phenotype, in which case breeding of the animal would no longer be continued.

\subsection{Concerns of plasmid and prokaryotic DNA sequence} contamination

The second issue, extraneous DNA contamination by plasmids and marker genes in GM animal genomes, may appear to be a potentially serious problem but it is not, as is best addressed by human studies. Generally, animal model systems are employed in biomedical studies before clinical trials in humans. However, for understanding natural chromosomal dynamics in vertebrates, human genomes are the best models because they have been the most intensively studied. The most astonishing finding has been the plasticity of genomes ${ }^{[83]}$. Initial human genome sequencing revealed that about $45 \%$ of the human genome was composed of easily identifiable transposable elements ${ }^{[84]}$. Later studies indicate that up to two-thirds of the human genome may be derived from invading viruses and transposons ${ }^{[85,86]}$. Although nearly all of the nearly 2.5 million transposons in human genomes are inactive, a few are not and these are linked to insertional mutagenesis in humans ${ }^{[87-89]}$. Surprisingly, high rates of mobilization of L1 transposons in human neuronal tissues ${ }^{[90,91]}$ have been reported. Transposable elements are not the only destabilizers in genomes. Deletions and duplications, collectively termed copy number variations (CNVs), may total $5 \%-9 \%$ of the human genome ${ }^{[92,93]}$. Genomes of vertebrate animals are similar to those in humans; a recent report identified $3538 \mathrm{CNV}$ regions in the porcine genome ${ }^{[94]}$.

Importantly from a regulatory point of view, plant genomes are just as unstable, if not more so, than human genomes. Transposable elements were first elucidated by Barbara McClintock in her studies of variably colored kernels in maize ${ }^{[95]}$. Nearly $85 \%$ of the reference maize genome is transposable elements ${ }^{[96]}$. This vast reservoir of mobile elements contributes to an immense diversity between lines of maize ${ }^{[97]}$. Thus, the exhaustive Borlaug field testing of hybridized maize genomes unknowingly resulted in genotypes that are far more diversified than thought previously. Regardless, many products of the global hybridizations were expanded because they were superior in select environments. There are several $21 \mathrm{st}$ century lessons from the Green Revolution. (1) Blind genetic manipulations of complex genomes have a halfcentury history of producing beneficial agricultural diversity that suggests precision genomic changes should be beneficial and safe as well. (2) Superficial examination of genomic changes brings a false sense of security in a regulatory arena. (3) A GM product is best evaluated on the basis of its phenotype rather than its genotype - it is the phenotype that consumers and regulators really care about.

The issue of the presence of prokaryotic DNA in GM animal genomes is another example of where regulatory policy is much ado about nothing. The basis for the concern of vector DNA, generally plasmids, and selectable marker genes for antibiotic resistance, appears to be about their potential expression in GM host cells. Since antibiotic genes in the environment are a concern ${ }^{[98,99]}$, the question becomes what happens when people consume such genes from a GM animal (or plant). The answer from two decades ago in the context of transgenic fish ${ }^{[100]}$ is that antibiotic resistance will not be passed on to the consumer for three reasons. (1) Bacterial and plasmid genes are not sufficiently expressed in animal cells for the reasons discussed earlier in the context of bacterial and animal/ plant genetic processing systems. (2) Expression of selectable marker genes is restricted to the cell in which 
they reside; if a cell is consumed by a human, the expression stops as a consequence of digestive processes. (3) Uptake of whole genes from either bacteria, animals or plants by human cells does not happen except through viral infection or elaborate laboratory procedures. If it were otherwise, human genomes would be destabilized by the greater than $10^{15}$ genes people consume daily.

Plasmids are not bad-people intentionally ingest uncountable numbers of plasmids. For example, sourdough breads and yogurts contain lactococci that are used in the manufacture of foods because they harbor particular plasmids that confer specific flavors ${ }^{[101]}$. Moreover, bacteria and their plasmids contribute to human microbiome ${ }^{[102-104]}$; the human gut is considered an antimicrobial resistance reservoir ${ }^{[105]}$. Recent studies of plasmids in human microbiomes suggest that plasmids and the genes they carry are actively swapped ${ }^{[106-108]}$ via natural processes that happen between bacterial cells but not between bacterial and human cells. Note that antibiotic resistance can be passed to humans through physicianprescribed fecal microbiota transplantation, an emerging therapy for certain bowel disorders ${ }^{[109]}$. In summary, we are swamped with plasmids and the microorganisms that harbor them. In general, outside of hospital environments where antibiotics are prevalent and patients are in various states of disability, few people have problems with plasmids in food.

Misunderstanding trumping science is common, as recently dramatized when a plasmid sequence was found in the genomes of GM polled dairy cows ${ }^{[110,111]}$. The net genetic consequence was the addition of about 3000 basepairs to a cow's diploid genome that contains roughly 3 billion basepairs of junk DNA, i.e., an addition of only one millionth $(0.0001 \%)$. Although overlooking the presence of plasmid sequence was deemed inexcusable, in fact the plasmid had no discernible effect on the GM animal and its polled offspring ${ }^{[111]}$. Nevertheless, a firestorm erupted from the news ${ }^{[12]}$. However, the real story is that a well-intentioned GM animal welfare project faced public condemnation as a result of outdated and over-restrictive regulations. A great step in animal welfare and ethics was derailed by a pointless detail of regulatory concerns.

\subsection{Concerns of transgene spread}

The third regulatory concern is that transgenes in GM animals might spread to other organisms, as exemplified by the mandate that the carcasses of GM animals be incinerated. Incineration is required due to the mistaken thought that transgenes can wander from one genome to another. This obviously does not happen. We are totally unafraid of animal and plant remains being discarded in dumps around the world. We know there are no health concerns of the discarded genomes other than spread of virulent agents such as infectious viruses and parasites. We know this because genes in dead organisms do not enter human genomes, even at doses of $10^{15}$ per meal.

In summary, there are no scientifically based safety concerns that would result from intelligent introduction of new traits into GM livestock. The costs of generating new animal genomes coupled with the costs of establishing a herd are such that intense scrutiny before and after the engineering will occur to avoid unimaginable adverse consequences being released to the public and the environment.

\section{The costs of regulatory failure to approve GM animals are mounting}

Recent outstanding reviews of the failure of regulation of GM animals cover both the problems and losses to agriculture and the public ${ }^{[38,113,114]}$. The fundamental knowledge generated from transgenic animal mod$\mathrm{els}^{[38,115-117]}$ has supported engineering of improved livestock; e.g., improvements in dairy milk ${ }^{[118,119]}$. Pigs have been engineered with the fat- 1 gene that encodes an enzyme that converts omega- 6 fatty acids of bacon into the omega-3 form found in fish ${ }^{[120,121]}$; it's not clear what the product tastes like. To address the problem of environmental pollution in the pork industry, a phytase transgenic pig was engineered that allows pigs to digest the phosphorus in the pig diet ${ }^{[122]}$. These GM animals were engineered by investigators with noble motives but, due to the genetically modified organism (GMO) tag, none of these animals was commercially viable. The same reluctance to the GMO label is evident by Florida orange farmers who have seen a $72 \%$ decline in the production of oranges by citrus greening ${ }^{[123]}$ yet they refrain from developing GM plants that would retard the disease. GE may be a solution for the Fusarium fungus strain TR4 that is severely devastating some Cavendish banana crops ${ }^{[124]}$. The anti-GMO sentiment gains support by regulatory hurdles that suggest safety concerns, even when there are none.

\section{How can regulatory agencies and the public be sure GM animals are safe?}

The world needs GM animals to provide nutrition with minimal environmental encroachment ${ }^{[125]}$. These products must be considered safe to the public to bring them into the market. Regulatory agencies do not validate products but they can certify that products do not have any apparent risks beyond those of progenitors of GM products. No one can prove a negative and agencies should not pretend that genetic engineers can.

Current methods of assessing risk are intrinsically flawed, ironically by the desire to approach risk assessment 
in a rigorous scientific manner. Figure 8 illustrates the problem. The scientific method is to break a problem down into parts that can be tested using controlled procedures that assure reproducibility. This sounds good. However, the natural world is characterized by innumerable confounding interactions and variables that are poorly understood. In the laboratory, financial constraints restrict the variables and conditions that can be tested. Hence, only a few of the myriad variables are examined and that inevitably leads to irrelevant results and publications that do not adequately address risk. This works out for the scientists who get academic credit and further grants to run more highly controlled experiments that produce more excellent papers. Regulators avoid having to make unpopular decisions because the risks remain unresolved. A shining example is illustrated by early laboratory tests at Cornell University that suggested that Bacillus thuringiensis toxin-expressing GM maize killed monarch butterflies $^{[127]}$. This Nature report caused a firestorm of letters from school children and others who bemoaned the extinction of America's favorite insect. This incident led many to condemn Monsanto Corporation as a company intent on increasing earnings at the expense of the environment ${ }^{[128]}$. Two years later a series of reports from studies conducted in several USA midwestern states showed that butterflies were not impacted ${ }^{[129-133]}$. In fact, an unanticipated result emerged-organic farms close to GM crop fields increased their productivity compared to distal organic farms ${ }^{[134]}$. Another example of misunderstanding is that of GM fish. They have been a subject of scrutiny because they are difficult to track. A theoretical paper suggested that the escape of a growthenhanced fish could lead to the demise of natural salmon stocks ${ }^{[135,136]}$ despite clear indications that this speculative extreme concern would not happen in nature ${ }^{[137]}$. The theory has been field tested with farmed Norwegian Atlantic salmon where the dire consequences have not occurred despite thousands of growth-enhanced salmon escaping from Norwegian net pens ${ }^{[138-140]}$. In nature only about $1 / 1000$ to $1 / 10000$ fish eggs reach sexual maturity. Realistically evaluating the risks of transgenic fish in the laboratory is impossible because of fiscal limitations on numbers of fish and their environmental conditions.

\section{Summary}

The damage from misplaced regulatory concerns lasts to this day. The inflammatory rhetoric by groups against GM products led to a delay of more than a decade of Golden Rice $^{[141,142]}$. The United Nations estimates that 250 million people suffer from vitamin A deficiency of whom an estimated 250000-500000 children are blinded. Many die within 12 months of losing their eyesight because various NGOs lobbied poor African countries to ban GM Golden Rice fortified with vitamin A. The problem persists even though a consortium of more than 100 Noble Prize winners condemned Greenpeace in particular and other NGOs in general for their position that amounted to crimes against humanity ${ }^{[143]}$.

It does not have to be this way ${ }^{[144]}$. There are current efforts to revise regulations on GM agricultural products in the USA with the $2015^{[145]}, 2017^{[71]}$ and $2019^{[39]}$ Executive Orders on Modernizing the Regulatory Framework for Agricultural Biotechnology Products. Similar efforts are ongoing in several other countries ${ }^{[40,41]}$. Many of these focus on the advances in precision GE, which serves to separate GE from recombinant DNA-based technologies ${ }^{[35,37,38]}$. Alas, this approach is far too limited. It will solve a current issue but will retard future applications of more sophisticated genetics. Genome engineering is still in its infancy, equivalent to when the Apple App Store had about one hundred choices rather than the millions today. Regulatory policy makers are stuck in innumerable process-oriented meetings that involve hundreds of individuals and organizations that are dependent on stagnation as they focus on legal minutiae while missing what the future portends, e.g., the 2019 Organization for Economic Co-operation and Development conference on $\mathrm{GE}^{[146]}$. If changes in regulatory policies of Genapps are to be made, they need to be

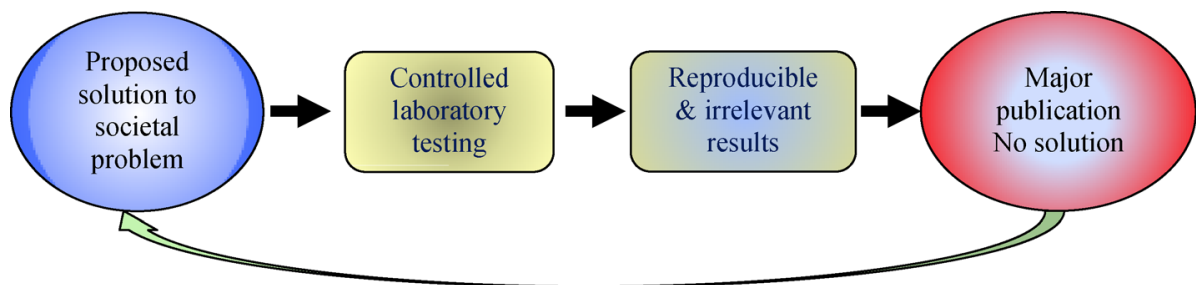

Fig. 8 The futile cycle of risk assessment of GM animals. Regulatory agencies put out Requests for Applications to solve complex problems. Scientists write proposals in which a complex problem is broken down into specific sub-problems that can be studied in a laboratory environment where in as many variables as possible are controlled to ensure reproducibility. The results of the studies are published in elite journals because the problems they address are important ${ }^{[126]}$. However, the experimental constraints of budgets, numbers of subjects, and control of environmental variables limit the applicability of the results to real-world issues. Hence, the problems remain unsolved for another cycle of inconclusive experimentation. 
effective for decades, not just in response to scientific advances that occur every few years.

There are four stages of future GM animal development. (1) the recombinant DNA stage ${ }^{[114]}$ wherein alterations are made by near random introduction of genetic sequenceswe are largely past that stage; (2) the GE (current) stage wherein small, single-locus changes are made, generally deletions, knockout mutations ${ }^{[147,148]}$ or introgression ${ }^{[74]}$ of existing DNA sequences from a related line or species; (3) the synthetic gene ${ }^{[149,150]}$ stage of the sort that might be most useful for disease resistance - this stage is awaiting go-ahead signals from regulatory agencies who understand the urgency with diseases such as African swine fever and avian influenza; and (4) the novel biochemical pathway stage that will be required to confer whole new phenotypes on top of existing structures, e.g., introduction of nutraceuticals into plants and animals for improved health (akin to the Golden Rice story). The latter changes will require far more regulatory latitude. We should anticipate these needs now if we are to maintain planetary integrity. The regulatory revisions I suggested earlier for GM animals will accomplish this goal - they are:

- Stop regulatory scrutiny by FDA of GM animals as new animal drugs - the concept is scientifically meaningless and unsupportable.

- Extend FDA discretionary authorization to allow agricultural GM animals into the marketplace in keeping with their policies on permitting the sales of GloFish.

- Maintain USDA-FSIS surveillance of GM animals.

- Most importantly, let the marketplace determine the GM alterations that have the most value for consumers. This action will recognize that geneticists, producers and breeders have the deepest insights into both the merits and deficits of genetic changes. These groups also have the most to lose by any misguided genetic changes that will not appeal to consumers.

GM is a powerful technology that can revolutionize the world in medicine and agriculture. As in gene therapy and molecular medicine, we have an obligation to exploit genetic technologies for the good of mankind ${ }^{[151-153]}$. That will require greater efforts to bring the public into conversations through open science-based forums such as those sponsored by the Genome Writers Guild ${ }^{[154]}$, a society committed to building a better future for humanity. This is what we all want and this is what regulatory agencies should enable and support.

Acknowledgements I am grateful for the thoughts and insights of many colleagues over the past three decades of working with transgenic animals. Drs. Mark Walton, Tad Sonstegard, and Elena Aronovich were kind enough to make suggestions even if dubious that my proposal would be accepted by anyone. I am appreciative of many other colleagues who have shared their thoughts with me on earlier proposals and reviewers who corrected errors and made important constructive suggestions. I am especially appreciative of regulators in the EPA, FDA and USDA who have listened to my views and offered their points of view while doing their best to comply with federal legal restrictions, politicians, and a diverse public.
Compliance with ethics guidelines Perry Bradbury Hackett is a cofounder and stockholder in three genome-engineering based companies, Discovery Genomics (acquired by Immusoft, Inc.), Recombinetics, Inc., and NovoClade, Inc. He declares that there is no conflict of interest or financial conflict to disclose.

This article is a review and does not contain any studies with human or animal subjects performed by the author.

\section{References}

1. Borlaug N. Feeding a hungry world. Science, 2007, 318(5849): 359

2. Ray D K, Mueller N D, West P C, Foley J A. Yield trends are insufficient to double global crop production by 2050. PLoS One, 2013, 8(6): e66428

3. Pingali P L. Green Revolution: impacts, limits, and the path ahead. Proceedings of the National Academy of Sciences of the United States, 2012, 109(31): 12302-12308

4. Borlaug N. Blasts GMO Doomsayers. Available at AgriBioWorld website on February 20, 2020

5. Food and Agriculture Organization of the United Nations (FAO). How to Feed the World in 2050. Rome: FAO, 2009. Available at FAO website on February 20, 2020

6. United Nations. Food Production Must Double by 2050 to Meet Demand from World's Growing Population, Innovative Strategies Needed to Combat Hunger, Experts Tell Second Committee, 2009. Available at United Nations website on February 20, 2020

7. The National Academies Press (NAS). Science breakthroughs to advance food and agricultural research by 2030. Washington, DC: The National Academies Press, 2019. Available at NAP website on February 20, 2020

8. Godfray H C J, Beddington J R, Crute I R, Haddad L, Lawrence D, Muir J F, Pretty J, Robinson S, Thomas S M, Toulmin C. Food security: the challenge of feeding 9 billion people. Science, 2010, 327(5967): 812-818

9. Hoekstra A Y, Wiedmann T O. Humanity's unsustainable environmental footprint. Science, 2014, 344(6188): 1114-1117

10. Bailey-Serres J, Parker J E, Ainsworth E A, Oldroyd G E D, Schroeder J I. Genetic strategies for improving crop yields. Nature, 2019, 575(7781): 109-118

11. Kaplan J O, Krumhardt K M, Ellis E C, Ruddiman W F, Lemmen C, Goldewijk K K. Holocene carbon emissions: a result of anthropogenic land cover change. Holocene, 2011, 21(5): 775-791

12. Graham-Rowe D. Agriculture: beyond food versus fuel. Nature, 2011, 474(7352): S6-S8

13. Conway G, Toenniessen G. Feeding the world in the twenty-first century. Nature, 1999, 402(S6761): C55-C58

14. Rands M R W, Adams W M, Bennun L, Butchart S H M, Clements A, Coomes D, Entwistle A, Hodge I, Kapos V, Scharlemann J P W, Sutherland W J, Vira B. Biodiversity conservation: challenges beyond 2010. Science, 2010, 329(5997): 1298-1303

15. Büntgen U, Tegel W, Nicolussi K, McCormick M, Frank D, Trouet V, Kaplan J O, Herzig F, Heussner K U, Wanner H, Luterbacher J, Esper J. 2500 years of European climate variability and human susceptibility. Science, 2011, 331(6017): 578-582 
16. Marcott S A, Shakun J D, Clark P U, Mix A C. A reconstruction of regional and global temperature for the past 11300 years. Science, 2013, 339(6124): 1198-1201

17. Eshed Y, Lippman Z B. Revolutions in agriculture chart a course for targeted breeding of old and new crops. Science, 2019, 366 (6466): eaax0025

18. Phelps L N, Kaplan J O. Land use for animal production in global change studies: defining and characterizing a framework. Global Change Biology, 2017, 23(11): 4457-4471

19. Sachs J, Remans R, Smukler S, Winowiecki L, Andelman S J, Cassman K G, Castle D, DeFries R, Denning G, Fanzo J, Jackson L E, Leemans R, Lehmann J, Milder J C, Naeem S, Nziguheba G, Palm C A, Pingali P L, Reganold J P, Richter D D, Scherr S J, Sircely J, Sullivan C, Tomich T P, Sanchez P A. Monitoring the world's agriculture. Nature, 2010, 466(7306): 558-560

20. Anastácio R, Pereira M J. From the challenges imposed by climate change to the preservation of ecosystem processes and services. Natural Resources, 2017, 8(12): 788-807

21. Kim H, Kim J S. A guide to genome engineering with programmable nucleases. Nature Reviews: Genetics, 2014, 15(5): 321-334

22. Anzalone A V, Randolph P B, Davis J R, Sousa A A, Koblan L W, Levy J M, Chen P J, Wilson C, Newby G A, Raguram A, Liu D R. Search-and-replace genome editing without double-strand breaks or donor DNA. Nature, 2019, 576(7785): 149-157

23. Tizard M, Hallerman E, Fahrenkrug S, Newell-McGloughlin M, Gibson J, de Loos F, Wagner S, Laible G, Han J Y, D’Occhio M, Kelly L, Lowenthal J, Gobius K, Silva P, Cooper C, Doran T. Strategies to enable the adoption of animal biotechnology to sustainably improve global food safety and security. Transgenic Research, 2016, 25(5): 575-595

24. Tizard M L, Jenkins K A, Cooper C A, Woodcock M E, Challagulla A, Doran T J. Potential benefits of gene editing for the future of poultry farming. Transgenic Research, 2019, 28(S2): 8792

25. Telugu B P, Park K E, Park C H. Genome editing and genetic engineering in livestock for advancing agricultural and biomedical applications. Mammalian Genome, 2017, 28(7-8): 338-347

26. Laible G. Production of transgenic livestock: overview of transgenic technologies. In: Niemann $\mathrm{H}$, Wrenzycki C, eds. Animal Biotechnology 2. Springer, 2018, 95-122

27. Niemann H, Seamark B. The evolution of farm animal biotechnology. In: Niemann H, Wrenzycki C, eds. Animal Biotechnology 1. Springer, 2018, 1-26

28. Yum S Y, Youn K Y, Choi W J, Jang G. Development of genome engineering technologies in cattle: from random to specific. Journal of Animal Science and Biotechnology, 2018, 9(1): 16

29. Lillico S. Agricultural applications of genome editing in farmed animals. Transgenic Research, 2019, 28(S2): 57-60

30. Kumar M, Yadav A K, Verma V, Singh B, Mal G, Nagpal R, Hemalatha R. Bioengineered probiotics as a new hope for health and diseases: an overview of potential and prospects. Future Microbiology, 2016, 11(4): 585-600

31. Lam H M, Remais J, Fung M C, Xu L, Sun S S M. Food supply and food safety issues in China. Lancet, 2013, 381(9882): 2044-2053

32. Mukhopadhyay K, Thomassin P J, Zhang J Y. Food security in
China at 2050: a global CGE exercise. Journal of Economic Structures, 2018, 7(1): 1

33. Cui K, Shoemaker S P. A look at food security in China. NPJ Science of Food, 2018, 2(1): 4

34. Fedoroff N V. Will common sense prevail? Trends in Genetics, 2013, 29(4): 188-189

35. Jones $\mathrm{H}$ D. Future of breeding by genome editing is in the hands of regulators. GM Crops and Food: Biotechnology in Agriculture and the Food Chain, 2015, 6(4): 223-232

36. Meghani Z. Genetically engineered animals, drugs, and neoliberalism: the need for a new biotechnology regulatory policy framework. Journal of Agricultural \& Environmental Ethics, 2017, 30(6): 715-743

37. Van Eenennaam A L. Application of genome editing in farm animals: cattle. Transgenic Research, 2019, 28(S2): 93-100

38. Van Eenennaam A L, Wells K D, Murray J D. Proposed U.S. regulation of gene-edited food animals is not fit for purpose. NPJ Science of Food, 2019, 3(1): 3

39. Whitehouse. Executive Order on Modernizing the Regulatory Framework for Agricultural Biotechnology Products, 2019. Available at Whitehouse website on February 20, 2020

40. Whelan A I, Lema M A. Regulatory framework for gene editing and other new breeding techniques (NBTs) in Argentina. GM Crops and Food: Biotechnology in Agriculture and the Food Chain, 2015, 6(4): 253-265

41. Thygesen P. Clarifying the regulation of genome editing in Australia: situation for genetically modified organisms. Transgenic Research, 2019, 28(S2): 151-159

42. Fernbach P M, Light N, Scott S E, Inbar Y, Rozin P. Extreme opponents of genetically modified foods know the least but think they know the most. Nature Human Behaviour, 2019, 3(3): 251256

43. Murray J D, Maga E A. Opinion: a new paradigm for regulating genetically engineered animals that are used as food. Proceedings of the National Academy of Sciences of the United States of America, 2016, 113(13): 3410-3413

44. Statista. Number of active apps from the Apple App Store 2008 2019. Available at Statista website on February 20, 2020

45. Maxmen A. Gay gene' provokes fears of a genetic wild west. Nature, 2019, 574: 609-610

46. Arber W, Linn S. DNA modification and restriction. Annual Review of Biochemistry, 1969, 38(1): 467-500

47. Wells K D. History and future of genetically engineered food animal regulation: an open request. Transgenic Research, 2016, 25 (3): 385-394

48. Shah K, Nathanson N. Human exposure to SV40: review and comment. American Journal of Epidemiology, 1976, 103(1): 112

49. Berg P, Baltimore D, Brenner S, Roblin R O 3rd, Singer M F. Summary statement of the Asilomar conference on recombinant DNA molecules. Proceedings of the National Academy of Sciences of the United States of America, 1975, 72(6): 1981-1984

50. Berg P, Singer M F. The recombinant DNA controversy: twenty years later. Proceedings of the National Academy of Sciences of the United States of America, 1995, 92(20): 9011-9013

51. Executive Office of the President, Office of Science and 
Technology Policy. Coordinated Framework for Regulation of Biotechnology. 1986. Available at the U.S. Department of Agriculture (USDA)-Animal and Plant Health Inspection Servive (APHIS) website on February 20, 2020

52. Van Eenennaam A L, Muir W M. Transgenic salmon: a final leap to the grocery shelf? Nature Biotechnology, 2011, 29(8): 706-710

53. Carroll D, Van Eenennaam A L, Taylor J F, Seger J, Voytas D F. Regulate genome-edited products, not genome editing itself. Nature Biotechnology, 2016, 34(5): 477-479

54. Lamppa G, Nagy F, Chua N H. Light-regulated and organ-specific expression of a wheat $\mathrm{Cab}$ gene in transgenic tobacco. Nature, 1985, 316(6030): 750-752

55. Jaenisch R, Mintz B. Simian virus 40 DNA sequences in DNA of healthy adult mice derived from preimplantation blastocysts injected with viral DNA. Proceedings of the National Academy of Sciences of the United States of America, 1974, 71(4): 12501254

56. Costantini F, Lacy E. Introduction of a rabbit $\beta$-globin gene into the mouse germ line. Nature, 1981, 294(5836): 92-94

57. Gordon J W, Ruddle F H. Integration and stable germ line transmission of genes injected into mouse pronuclei. Science, 1981, 214(4526): 1244-1246

58. Palmiter R D, Brinster R L, Hammer R E, Trumbauer M E, Rosenfeld M G, Birnberg N C, Evans R M. Dramatic growth of mice that develop from eggs microinjected with metallothioneingrowth hormone fusion genes. Nature, 1982, 300(5893): 611615

59. Zhu Z, Li G, He L, Chen S. Novel gene transfer into the fertilized eggs of gold fish (Carassius auratus L. 1758). Journal of Applied Ichthyology, 1985, 1(1): 31-34

60. Peng W. GM crop cultivation surges, but novel traits languish. Nature Biotechnology, 2011, 29(4): 302

61. International Service for the Acquisition of Agri-Biotech Applications (ISAAA). Crop Bitech Update. Available at ISAAA website on February 20, 2020

62. Carlson R. Estimating the biotech sector's contribution to the US economy. Nature Biotechnology, 2016, 34(3): 247-255

63. Hackett P, Carroll D F. Regulatory hurdles for agriculture GMOs. Science, 2015, 347(6228): 1324

64. United States Department of Agriculture (USDA)-National Agricultural Research, Extension, Education, and Economics Advisory Board (NAREEEAB). Use of Genetic Engineering in USDA Research. Available at USDA-NAREEEAB website on February 20, 2020

65. United States Department of Agriculture (USDA)-Animal and Plant Health Inspection Servive (APHIS). Secretary Perdue Issues USDA Statement on Plant Breeding Innovation. Available at USDA-APHIS website on February 2020

66. DeFrancesco L. How safe does transgenic food need to be? Nature Biotechnology, 2013, 31(9): 794-802

67. Postlethwait J H, Schneiderman H A. A clonal analysis of determination in Antennapedia a homoeotic mutant of Drosophilamelanogaster. Proceedings of the National Academy of Sciences of the United States of America, 1969, 64(1): 176-183

68. Miller H I, Kershen D L. US Congress mandates silliness, USDA complies. Nature Biotechnology, 2019, 37(5): 497-498
69. Pew Research Center. Most Americans Accept Genetic Engineering of Animals That Benefits Human Health, But Many Oppose Other Uses, 2019. Available at Pew Research Center website on February 20, 2020

70. Pew Research Center. Public Perspectives on Food Risks, 2018. Available at Pew Research Center website on February 20, 2020

71. U.S. Food and Drug Administration (FDA). Guidance for Industry \#187, 2017. Available at FDA website on February 20, 2020

72. U.S. Food and Drug Administration (FDA). Pathogens and Filth in Spices, 2013. Available at FDA website on Feburary 20, 2020

73. Kwit C, Moon H S, Warwick S I, Stewart C N Jr. Transgene introgression in crop relatives: molecular evidence and mitigation strategies. Trends in Biotechnology, 2011, 29(6): 284-293

74. Ahmad N, Mukhtar Z. Genetic manipulations in crops: challenges and opportunities. Genomics, 2017, 109(5-6): 494-505

75. Maga E A, Murray J D. Welfare applications of genetically engineered animals for use in agriculture. Journal of Animal Science, 2010, 88(4): 1588-1591

76. Carlson D F, Lancto C A, Zang B, Kim E S, Walton M, Oldeschulte D, Seabury C, Sonstegard T S, Fahrenkrug S C. Production of hornless dairy cattle from genome-edited cell lines. Nature Biotechnology, 2016, 34(5): 479-481

77. Porto-Neto L R, Bickhart D M, Landaeta-Hernandez A J, Utsunomiya Y T, Pagan M, Jimenez E, Hansen P J, Dikmen S, Schroeder S G, Kim E S, Sun J, Crespo E, Amati N, Cole J B, Null D J, Garcia J F, Reverter A, Barendse W, Sonstegard T S. Convergent evolution of slick coat in cattle through truncation mutations in the prolactin receptor. Frontiers in Genetics, 2018, 9 (9): 57

78. Howe S J, Mansour M R, Schwarzwaelder K, Bartholomae C, Hubank M, Kempski H, Brugman M H, Pike-Overzet K, Chatters S J, de Ridder D, Gilmour K C, Adams S, Thornhill S I, Parsley K L, Staal F J T, Gale R E, Linch D C, Bayford J, Brown L, Quaye M, Kinnon C, Ancliff P, Webb D K, Schmidt M, von Kalle C, Gaspar $\mathrm{H} \mathrm{B}$, Thrasher A J. Insertional mutagenesis combined with acquired somatic mutations causes leukemogenesis following gene therapy of SCID-X1 patients. Journal of Clinical Investigation, 2008, 118(9): 3143-3150

79. Cavazza A, Moiani A, Mavilio F. Mechanisms of retroviral integration and mutagenesis. Human Gene Therapy, 2013, 24(2): 119-131

80. Ghosh S, Thrasher A J, Gaspar H B. Gene therapy for monogenic disorders of the bone marrow. British Journal of Haematology, 2015, 171(2): 155-170

81. Cesana D, Ranzani M, Volpin M, Bartholomae C, Duros C, Artus A, Merella S, Benedicenti F, Sergi Sergi L, Sanvito F, Brombin C, Nonis A, Serio C D, Doglioni C, von Kalle C, Schmidt M, CohenHaguenauer O, Naldini L, Montini E. Uncovering and dissecting the genotoxicity of self-inactivating lentiviral vectors in vivo. Molecular Therapy, 2014, 22(4): 774-785

82. Hackett P B, Starr T K, Cooper L J N. Chapter 5-Risks of insertional mutagenesis by DNA transposons in cancer gene therapy. In: Translating Gene Therapy to the Clinic: Techniques and Approaches. Translational Research: The Journal of Laboratory and Clinical Medicine, 2015, 65-83

83. Supek F, Lehner B. Scales and mechanisms of somatic mutation 
rate variation across the human genome. DNA Repair, 2019, 81: 102647

84. Lander E S, Linton L M, Birren B, Nusbaum C, Zody M C, Baldwin J, Devon K, Dewar K, Doyle M, FitzHugh W, Funke R, Gage D, Harris K, Heaford A, Howland J, Kann L, Lehoczky J, LeVine R, McEwan P, McKernan K, Meldrim J, Mesirov J P, Miranda C, Morris W, Naylor J, Raymond C, Rosetti M, Santos R, Sheridan A, Sougnez C, Stange-Thomann Y, Stojanovic N, Subramanian A, Wyman D, Rogers J, Sulston J, Ainscough R, Beck S, Bentley D, Burton J, Clee C, Carter N, Coulson A, Deadman R, Deloukas P, Dunham A, Dunham I, Durbin R, French L, Grafham D, Gregory S, Hubbard T, Humphray S, Hunt A, Jones M, Lloyd C, McMurray A, Matthews L, Mercer S, Milne S, Mullikin J C, Mungall A, Plumb R, Ross M, Shownkeen R, Sims S, Waterston R H, Wilson R K, Hillier L W, McPherson J D, Marra M A, Mardis E R, Fulton L A, Chinwalla A T, Pepin K H, Gish W R, Chissoe S L, Wendl M C, Delehaunty K D, Miner T L, Delehaunty A, Kramer J B, Cook L L, Fulton R S, Johnson D L, Minx P J, Clifton S W, Hawkins T, Branscomb E, Predki P, Richardson P, Wenning S, Slezak T, Doggett N, Cheng J F, Olsen A, Lucas S, Elkin C, Uberbacher E, Frazier M, Gibbs R A, Muzny D M, Scherer S E, Bouck J B, Sodergren E J, Worley K C, Rives C M, Gorrell J H, Metzker M L, Naylor S L, Kucherlapati R S, Nelson D L, Weinstock G M, Sakaki Y, Fujiyama A, Hattori M, Yada T, Toyoda A, Itoh T, Kawagoe C, Watanabe H, Totoki Y, Taylor T, Weissenbach J, Heilig R, Saurin W, Artiguenave F, Brottier P, Bruls T, Pelletier E, Robert C, Wincker P, Smith D R, Doucette-Stamm L, Rubenfield M, Weinstock K, Lee H M, Dubois J, Rosenthal A, Platzer M, Nyakatura G, Taudien S, Rump A, Yang H, Yu J, Wang J, Huang G, Gu J, Hood L, Rowen L, Madan A, Qin S, Davis R W, Federspiel N A, Abola A P, Proctor M J, Myers R M, Schmutz J, Dickson M, Grimwood J, Cox D R, Olson M V, Kaul R, Raymond C, Shimizu N, Kawasaki K, Minoshima S, Evans G A, Athanasiou M, Schultz R, Roe B A, Chen F, Pan H, Ramser J, Lehrach H, Reinhardt R, McCombie W R, de la Bastide M, Dedhia N, Blöcker H, Hornischer K, Nordsiek G, Agarwala R, Aravind L, Bailey J A, Bateman A, Batzoglou S, Birney E, Bork P, Brown D G, Burge C B, Cerutti L, Chen H C, Church D, Clamp M, Copley R R, Doerks T, Eddy S R, Eichler E E, Furey T S, Galagan J, Gilbert J G, Harmon C, Hayashizaki Y, Haussler D, Hermjakob H, Hokamp K, Jang W, Johnson L S, Jones T A, Kasif S, Kaspryzk A, Kennedy S, Kent W J, Kitts P, Koonin E V, Korf I, Kulp D, Lancet D, Lowe T M, McLysaght A, Mikkelsen T, Moran J V, Mulder N, Pollara V J, Ponting C P, Schuler G, Schultz J, Slater G, Smit A F, Stupka E, Szustakowki J, Thierry-Mieg D, Thierry-Mieg J, Wagner L, Wallis J, Wheeler R, Williams A, Wolf Y I, Wolfe K H, Yang S P, Yeh R F, Collins F, Guyer M S, Peterson J, Felsenfeld A, Wetterstrand K A, Patrinos A, Morgan M J, de Jong P, Catanese J J, Osoegawa K, Shizuya H, Choi S, Chen Y J, Szustakowki J. Initial sequencing and analysis of the human genome. Nature, 2001, 409(6822): 860-921

85. Cordaux R. The human genome in the LINE of fire. Proceedings of the National Academy of Sciences of the United States of America, 2008, 105(49): 19033-19034

86. de Koning A P J, Gu W, Castoe T A, Batzer M A, Pollock D D. Repetitive elements may comprise over two-thirds of the human genome. PLoS Genetics, 2011, 7(12): e1002384

87. Ade C, Roy-Engel A M, Deininger P L. Alu elements: an intrinsic source of human genome instability. Current Opinion in Virology, 2013, 3(6): 639-645

88. Garcia-Perez J L, Widmann T J, Adams I R. The impact of transposable elements on mammalian development. Development, 2016, 143(22): 4101-4114

89. Gardner E J, Prigmore E, Gallone G, Danecek P, Samocha K E, Handsaker J, Gerety S S, Ironfield H, Short P J, Sifrim A, Singh T, Chandler K E, Clement E, Lachlan K L, Prescott K, Rosser E, FitzPatrick D R, Firth H V, Hurles M E. Contribution of retrotransposition to developmental disorders. Nature Communications, 2019, 10(1): 4630

90. Richardson S R, Morell S, Faulkner G J. L1 retrotransposons and somatic mosaicism in the brain. Annual Review of Genetics, 2014, 48(1): $1-27$

91. Larsen P A, Hunnicutt K E, Larsen R J, Yoder A D, Saunders A M. Warning SINEs: Alu elements, evolution of the human brain, and the spectrum of neurological disease. Chromosome Research, 2018, 26(1-2): 93-111

92. Zarrei M, MacDonald J R, Merico D, Scherer S W. A copy number variation map of the human genome. Nature Reviews: Genetics, 2015, 16(3): 172-183

93. Lauer S, Gresham D. An evolving view of copy number variants. Current Genetics, 2019, 65(6): 1287-1295

94. Keel B N, Nonneman D J, Lindholm-Perry A K, Oliver W T, Rohrer G A. A survey of copy number variation in the porcine genome detected from whole-genome sequence. Frontiers in Genetics, 2019, 10: 737

95. Federoff N V. Maize transposable elements in development and evolution. Integrative and Comparative Biology, 1989, 29(2): 549-555

96. Schnable P S, Ware D, Fulton R S, Stein J C, Wei F, Pasternak S, Liang C, Zhang J, Fulton L, Graves T A, Minx P, Reily A D, Courtney L, Kruchowski S S, Tomlinson C, Strong C, Delehaunty K, Fronick C, Courtney B, Rock S M, Belter E, Du F, Kim K, Abbott R M, Cotton M, Levy A, Marchetto P, Ochoa K, Jackson S M, Gillam B, Chen W, Yan L, Higginbotham J, Cardenas M, Waligorski J, Applebaum E, Phelps L, Falcone J, Kanchi K, Thane T, Scimone A, Thane N, Henke J, Wang T, Ruppert J, Shah N, Rotter K, Hodges J, Ingenthron E, Cordes M, Kohlberg S, Sgro J, Delgado B, Mead K, Chinwalla A, Leonard S, Crouse K, Collura K, Kudrna D, Currie J, He R, Angelova A, Rajasekar S, Mueller T, Lomeli R, Scara G, Ko A, Delaney K, Wissotski M, Lopez G, Campos D, Braidotti M, Ashley E, Golser W, Kim H, Lee S, Lin J, Dujmic Z, Kim W, Talag J, Zuccolo A, Fan C, Sebastian A, Kramer M, Spiegel L, Nascimento L, Zutavern T, Miller B, Ambroise C, Muller S, Spooner W, Narechania A, Ren L, Wei S, Kumari S, Faga B, Levy M J, McMahan L, Van Buren P, Vaughn M W, Ying K, Yeh C T, Emrich S J, Jia Y, Kalyanaraman A, Hsia A P, Barbazuk W B, Baucom R S, Brutnell T P, Carpita N C, Chaparro C, Chia J M, Deragon J M, Estill J C, Fu Y, Jeddeloh J A, Han Y, Lee H, Li P, Lisch D R, Liu S, Liu Z, Nagel D H, McCann M C, SanMiguel P, Myers A M, Nettleton D, Nguyen J, Penning B W, Ponnala L, Schneider K L, Schwartz D C, Sharma A, Soderlund C, Springer N M, Sun Q, Wang H, Waterman M, Westerman R, 
Wolfgruber T K, Yang L, Yu Y, Zhang L, Zhou S, Zhu Q, Bennetzen J L, Dawe R K, Jiang J, Jiang N, Presting G G, Wessler S R, Aluru S, Martienssen R A, Clifton S W, McCombie W R, Wing R A, Wilson R K. The B73 maize genome: complexity, diversity, and dynamics. Science, 2009, 326(5956): 1112-1115

97. Jiao Y, Peluso P, Shi J, Liang T, Stitzer M C, Wang B, Campbell M S, Stein J C, Wei X, Chin C S, Guill K, Regulski M, Kumari S, Olson A, Gent J, Schneider K L, Wolfgruber T K, May M R, Springer N M, Antoniou E, McCombie W R, Presting G G, McMullen M, Ross-Ibarra J, Dawe R K, Hastie A, Rank D R, Ware D. Improved maize reference genome with single-molecule technologies. Nature, 2017, 546(7659): 524-527

98. Berendonk T U, Manaia C M, Merlin C, Fatta-Kassinos D, Cytryn E, Walsh F, Bürgmann H, Sørum H, Norström M, Pons M N, Kreuzinger N, Huovinen P, Stefani S, Schwartz T, Kisand V, Baquero F, Martinez J L. Tackling antibiotic resistance: the environmental framework. Nature Reviews: Microbiology, 2015, 13(5): 310-317

99. Stalder T, Press M O, Sullivan SLiachko I, Top E M. Linking the resistome and plasmidome to the microbiome. The ISME Journal: Multidisciplinary Journal of Microbial Ecology, 2019, 13: 24372446

100. Hackett P B, Alvarez M C. The molecular genetics of transgenic fish. Recent Biotechnology Advances Articles, 2000, 4(Part B): 77145

101. Mills S, McAuliffe O E, Coffey A, Fitzgerald G F, Ross R P. Plasmids of lactococci-genetic accessories or genetic necessities? FEMS Microbiology Reviews, 2006, 30(2): 243-273

102. Sender R, Fuchs S, Milo R. Revised estimates for the number of human and bacteria cells in the body. PLoS Biology, 2016, 14(8): e1002533

103. Nelson K E, Weinstock G M, Highlander S K, Worley K C, Creasy H H, Wortman J R, Rusch D B, Mitreva M, Sodergren E, Chinwalla A T, Feldgarden M, Gevers D, Haas B J, Madupu R, Ward D V, Birren B W, Gibbs R A, Methe B, Petrosino J F, Strausberg R L, Sutton G G, White O R, Wilson R K, Durkin S, Giglio M G, Gujja S, Howarth C, Kodira C D, Kyrpides N, Mehta T, Muzny D M, Pearson M, Pepin K, Pati A, Qin X, Yandava C, Zeng Q, Zhang L, Berlin A M, Chen L, Hepburn T A, Johnson J, McCorrison J, Miller J, Minx P, Nusbaum C, Russ C, Sykes S M, Tomlinson C M, Young S, Warren W C, Badger J, Crabtree J, Markowitz V M, Orvis J, Cree A, Ferriera S, Fulton L L, Fulton R S, Gillis M, Hemphill L D, Joshi V, Kovar C, Torralba M, Wetterstrand K A, Abouellleil A, Wollam A M, Buhay C J, Ding Y, Dugan S, FitzGerald M G, Holder M, Hostetler J, Clifton S W, Allen-Vercoe E, Earl A M, Farmer C N, Liolios K, Surette M G, Xu Q, Pohl C, Wilczek-Boney K, Zhu D. A catalog of reference genomes from the human microbiome. Science, 2010, 328(5981): 994-999

104. Ó Cuív P, Aguirre de Cárcer D, Jones M, Klaassens E S, Worthley D L, Whitehall V L J, Kang S, McSweeney C S, Leggett B A, Morrison M. The effects from DNA extraction methods on the evaluation of microbial diversity associated with human colonic tissue. Microbial Ecology, 2011, 61(2): 353-362

105. Huddleston J R. Horizontal gene transfer in the human gastrointestinal tract: potential spread of antibiotic resistance genes. Infection and Drug Resistance, 2014, 7: 167-176

106. Cui Y, Hu T, Qu X, Zhang L, Ding Z, Dong A. Plasmids from food lactic acid bacteria: diversity, similarity, and new developments. International Journal of Molecular Sciences, 2015, 16(6): 1317213202

107. Sitaraman R. Prokaryotic horizontal gene transfer within the human holobiont: ecological-evolutionary inferences, implications and possibilities. Microbiome, 2018, 6(1): 163

108. Jeong H, Arif B, Caetano-Anollés G, Kim K M, Nasir A. Horizontal gene transfer in human-associated microorganisms inferred by phylogenetic reconstruction and reconciliation. Scientific Reports, 2019, 9(1): 5953

109. DeFilipp Z, Bloom P P, Torres Soto M, Mansour M K, Sater M R A, Huntley M H, Turbett S, Chung R T, Chen Y B, Hohmann E L. Drug-resistant $E$. coli bacteremia transmitted by fecal microbiota transplant. New England Journal of Medicine, 2019, 381(21): 2043-2050

110. Norris A L, Lee S S, Greenlees K J, Tadesse D A, Miller M F, Lombardi H A. Template plasmid integration in germline genomeedited cattle. Nature Biotechnology, 2020, 38(2): 163-164

111. Young A E, Mansour T A, McNabb B R, Owen J R, Trott J F, Brown C T, Van Eenennaam A L. Genomic and phenotypic analyses of six offspring of a genome-edited hornless bull. Nature Biotechnology, 2020, 38(2): 225-232

112. Molteni M A. Cow, a Controversy, and a Dashed Dream of More Humane Farms. Wired 10.08.2019. Available at wired website on February 20, 2020

113. Bruce A, Castle D, Gibbs C, Tait J, Whitelaw C B A. Novel GM animal technologies and their governance. Transgenic Research, 2013, 22(4): 681-695

114. Bruce A. Genome edited animals: learning from GM crops? Transgenic Research, 2017, 26(3): 385-398

115. Wall R J, Kerr D E, Bondioli K R. Transgenic dairy cattle: genetic engineering on a large scale. Journal of Dairy Science, 1997, 80 (9): 2213-2224

116. Tan W S, Carlson D F, Walton M W, Fahrenkrug S C, Hackett P B. Precision editing of large animal genomes. Advances in Genetics, 2012, 80: 37-97

117. Van Eenennaam A L. Genetic modification of food animals. Current Opinion in Biotechnology, 2017, 44: 27-34

118. Maga E A, Cullor J S, Smith W, Anderson G B, Murray J D. Human lysozyme expressed in the mammary gland of transgenic dairy goats can inhibit the growth of bacteria that cause mastitis and the cold-spoilage of milk. Foodborne Pathogens and Disease, 2006, 3(4): 384-392

119. Cooper C A, Maga E A, Murray J D. Production of human lactoferrin and lysozyme in the milk of transgenic dairy animals: past, present, and future. Transgenic Research, 2015, 24(4): 605614

120. Lai L, Kang J X, Li R, Wang J, Witt W T, Yong H Y, Hao Y, Wax D M, Murphy C N, Rieke A, Samuel M, Linville M L, Korte S W, Evans R W, Starzl T E, Prather R S, Dai Y. Generation of cloned transgenic pigs rich in omega-3 fatty acids. Nature Biotechnology, 2006, 24(4): 435-436

121. Pan D, Zhang L, Zhou Y, Feng C, Long C, Liu X, Wan R, Zhang J, Lin A, Dong E, Wang S, Xu H, Chen H. Efficient production of 
omega-3 fatty acid desaturase (sFat-1)-transgenic pigs by somatic cell nuclear transfer. Science China. Life Sciences, 2010, 53(4): 517-523

122. Golovan S P, Meidinger R G, Ajakaiye A, Cottrill M, Wiederkehr M Z, Barney D J, Plante C, Pollard J W, Fan M Z, Hayes M A, Laursen J, Hjorth J P, Hacker R R, Phillips J P, Forsberg C W. Pigs expressing salivary phytase produce low-phosphorus manure. Nature Biotechnology, 2001, 19(8): 741-745

123. Zhang C C. Citrus greening is killing the world's orange trees. Scientists are racing to help. Chemical and Engineering News, 2019, 97(23): 31-35

124. Maxmen A. CRISPR might be the banana's only hope against a deadly fungus. Nature, 2019, 574(7776): 15

125. Tait-Burkard C, Doeschl-Wilson A, McGrew M J, Archibald A L, Sang H M, Houston R D, Whitelaw C B, Watson M. Livestock 2.0 - genome editing for fitter, healthier, and more productive farmed animals. Genome Biology, 2018, 19(1): 204

126. Hackett P B, Fahrenkrug S C, Carlson D F. The promises and challenges of precision gene editing in animals of agricultural importance. In: Eaglesham A, Hardy R W F, eds. New DNAEditing Approaches: Methods, Applications and Policy for Agriculture. NABC Report 26, 2015, 39-52

127. Losey J E, Rayor L S, Carter M E. Transgenic pollen harms monarch larvae. Nature, 1999, 399(6733): 214

128. Schurman R, Munro W A. Fighting for the Future of Food. Minneapolis, USA: University of Minnesota Press, 2010

129. Hellmich R L, Siegfried B D, Sears M K, Stanley-Horn D E, Daniels M J, Mattila H R, Spencer T, Bidne K G, Lewis L C. Monarch larvae sensitivity to Bacillus thuringiensis-purified proteins and pollen. Proceedings of the National Academy of Sciences of the United States of America, 2001, 98(21): 1192511930

130. Oberhauser K S, Prysby M D, Mattila H R, Stanley-Horn D E, Sears M K, Dively G, Olson E, Pleasants J M, Lam W K F, Hellmich R L. Temporal and spatial overlap between monarch larvae and corn pollen. Proceedings of the National Academy of Sciences of the United States of America, 2001, 98(21): 1191311918

131. Sears M K, Hellmich R L, Stanley-Horn D E, Oberhauser K S, Pleasants J M, Mattila H R, Siegfried B D, Dively G P. Impact of Bt corn pollen on monarch butterfly populations: a risk assessment. Proceedings of the National Academy of Sciences of the United States of America, 2001, 98(21): 11937-11942

132. Stanley-Horn D E, Dively G P, Hellmich R L, Mattila H R, Sears M K, Rose R, Jesse L C H, Losey J E, Obrycki J J, Lewis L. Assessing the impact of CrylAb-expressing corn pollen on monarch butterfly larvae in field studies. Proceedings of the National Academy of Sciences of the United States of America, 2001, 98(21): 11931-11936

133. Zangerl A R, McKenna D, Wraight C L, Carroll M, Ficarello P, Warner R, Berenbaum M R. Effects of exposure to event 176 Bacillus thuringiensis corn pollen on monarch and black swallowtail caterpillars under field conditions. Proceedings of the National Academy of Sciences of the United States of America, 2001, 98 (21): 11908-11912

134. Hutchison W D, Burkness E C, Mitchell P D, Moon R D, Leslie T
W, Fleischer S J, Abrahamson M, Hamilton K L, Steffey K L, Gray M E, Hellmich R L, Kaster L V, Hunt T E, Wright R J, Pecinovsky K, Rabaey T L, Flood B R, Raun E S. Areawide suppression of European corn borer with $\mathrm{Bt}$ maize reaps savings to non-Bt maize growers. Science, 2010, 330(6001): 222-225

135. Muir W M, Howard R D. Assessment of possible ecological risks and hazards of transgenic fish with implications for other sexually reproducing organisms. Transgenic Research, 2002, 11(2): 101114

136. Devlin R H, Sundström L F, Muir W M. Interface of biotechnology and ecology for environmental risk assessments of transgenic fish. Trends in Biotechnology, 2006, 24(2): 89-97

137. Hackett P B. Genetic engineering: what are we fearing? Transgenic Research, 2002, 11(2): 97-99

138. Glover K A, Quintela M, Wennevik V, Besnier F, Sørvik A G E, Skaala $\varnothing$. Three decades of farmed escapees in the wild: a spatiotemporal analysis of Atlantic salmon population genetic structure throughout Norway. PLoS One, 2012, 7(8): e43129

139. Skilbrei $O \mathrm{~T}$, Heino $M$, Svåsand $T$. Using simulated escape events to assess the annual numbers and destinies of escaped farmed Atlantic salmon of different life stages from farm sites in Norway. ICES Journal of Marine Science, 2014, 72(2): 670-685

140. Harvey A C, Skilbrei O T, Besnier F, Solberg M F, Sørvik A E, Glover K A. Implications for introgression: has selection for fast growth altered the size threshold for precocious male maturation in domesticated Atlantic salmon? BMC Evolutionary Biology, 2018, 18(1): 188

141. Enserink M. Tough lessons from golden rice. Science, 2008, 320 (5875): 468-471

142. Owens B. Golden Rice is safe to eat, says FDA. Nature Biotechnology, 2018, 36(7): 559-560

143. Washington Post.107 Nobel laureates sign letter blasting Greenpeace over GMOs. Available at Washington Post website on February 20, 2020

144. McHughen A. A critical assessment of regulatory triggers for products of biotechnology: product vs. process. GM Crops and Food: Biotechnology in Agriculture and the Food Chain, 2016, 7 (3-4): $125-158$

145. U.S. Food and Drug Administration (FDA). Modernizing the Regulatory System for Plant and Animal Biotechnology Products, 2015. Available at FDA website on February 20, 2020

146. Friedrichs S, Takasu Y, Kearns P, Dagallier B, Oshima R, Schofield J, Moreddu C. Meeting report of the OECD conference on genome editing: applications in agriculture-implications for health, environment and regulation. Transgenic Research, 2019, 28 (3-4): 419-463

147. Carlson D F, Tan W, Hackett P B, Fahrenkrug S C. Editing livestock genomes with site-specific nucleases. Reproduction, Fertility, and Development, 2013, 26(1): 74-82

148. Tan W, Carlson D F, Lancto C A, Garbe J R, Webster D A, Hackett $\mathrm{P}$ B, Fahrenkrug S C. Efficient nonmeiotic allele introgression in livestock using custom endonucleases. Proceedings of the National Academy of Sciences of the United States of America, 2013, 110 (41): 16526-16531

149. Acevedo-Rocha C.G, Budisa N. Xenomicrobiology: a roadmap for genetic code engineering. Microbial Microbiology, 2016, 9(5): 


\section{6-676}

150. The Economist. The (April 6, 2019) Redesigning life - the promise of synthetic biology. Available at the Economist website on February 20, 2020

151. Fong Y, Hackett P B. Acceptance and access to gene editing: science and our obligations to mankind. Molecular Therapy, 2017, 25(1): $1-2$

152. Bruce A, Bruce D. Genome editing and responsible innovation, can they be reconciled? Journal of Agricultural \& Environmental
Ethics, 2019, 32(5-6): 769-788

153. Wang X, Chen Y, Sonstegard T S, Hackett P B, Fan Z, Li K. Meeting report on the 2019 international symposium of molecular design breeding in animals (Yangling, China) with the consensus on genome-editing agricultural animals and their regulation. Transgenic Research, 2020, 29(2): 263-265

154. Genome Writers Guild (GWG). A better future for humanity through genome engineering and public education. Available at GWG website on February 20, 2020 